\title{
Policies and Strategies for Revitalizing America's Manufacturing Communities
}

\author{
Andrew Stettner \\ The Century Foundation \\ Joel S. Yudken \\ High Road Strategies, LLC
}

After decades of decline and political indifference, U.S. manufacturing is getting fresh attention, in national elections and in research about economic disparities between communities and America's technological leadership. For the past two years, the authors of this report have worked on two-year project, sponsored by The Century Foundation (TCF) and its Bernard L. Schwartz Rediscovering Government Initiative (RGI), to elaborate on the contours of a policy that will not only revitalize the manufacturing industry, but lift the fortunes of struggling communities (urban, rural, and suburban) that have long looked to manufacturing as a source of good paying jobs and economic growth. The two-year project included three major research reports and interactions with nearly 500 stakeholders at community events throughout the industrial Midwest. The paper summarizes the research and (i) discusses why manufacturing remains important, (ii) presents a comprehensive framework for regional industrial policies best practices, and (iii) suggests the key state and federal policies and actions needed to revitalize manufacturing communities. The comprehensive framework identifies two major national policy drivers (trade and government purchasing) and four regional drivers (innovation, industrial retention, workforce and capital) that are all needed for U.S. manufacturing to recapture its economic promise.

Keywords: Manufacturing, Economic Development, Midwest, Industrial Policy

\section{INTRODUCTION}

After decades of decline and political indifference, U.S. manufacturing is getting fresh attention. The 2016 election (and the 2012 election before it) showed the political potency of manufacturing as an election issue, especially in critical swing states in the Great Lakes region. Meanwhile, recent research has underscored the consequences of the loss of good paying manufacturing jobs for communities across the United States, as well as the ramifications of declining industrial capacity on America's ability to be a world technological leader (Autor et.al., 2013; Pisano \& Shih, 2009). This has led to a robust debate about the value of manufacturing and the need for American industrial policy.

For the past two years, the authors of this report have worked on a two-year project, sponsored by The Century Foundation (TCF) and its Bernard L. Schwartz Rediscovering Government Initiative (RGI), 
to elaborate on the contours of a policy that will not only revitalize the manufacturing industry, but lift the fortunes of struggling communities (urban, rural, and suburban) that have long looked to manufacturing as a source of good paying jobs and economic growth. The project is part of TCF's High Wage America (HWA) initiative, supported by the Bernard L. Schwartz Rediscovering Government Initiative and The Joyce Foundation, which thus far has produced three major original research papers: "Why Manufacturing Jobs are Worth Saving" (Stettner, et.al., 2017), "Revitalizing America's Manufacturing Communities" (Yudken, et.al., 2018), and "A Federal Agenda to Revitalize Manufacturing Communities" (Stettner \& Yudken, 2018). In addition to policy and economic research, the project organized a series of in-person listening events in the Great Lakes industrial region historically referred to as the Rust Belt that was organized with a steering committee of scholars and manufacturing practitioners. More than 500 political, academic, business, labor, and community leaders and experts participated in summits in Pittsburgh (October 2017), Cleveland (March 2018), and Chicago (June 2018), and each summit was paired with original research on the manufacturing economy in these communities. These events and their corresponding research are reflected in the action model described below.

The paper will review and discuss the findings of the three major reports produced for the HWA project, which. The paper will (i) discuss why manufacturing remains important, (ii) present a comprehensive framework for regional industrial policies best practices, and (iii) suggest the key state and federal policies and actions needed to revitalize manufacturing communities.

\section{WHY MANUFACTURING REMAINS IMPORTANT}

The prominent role given manufacturing jobs by President Trump during his election campaign spurred CNN to declare that "American Manufacturing Is Having a Moment" in 2017; and the Trump administration has kept manufacturing in the news through its pledge to renegotiate NAFTA to create a North American manufacturing powerhouse and other aggressive trade policies (Gillespie, 2017; Thomas \& Gillies, 2018). But the new focus on manufacturing was started by President Obama, who rode his rescue of General Motors and Chrysler to his 2012 re-election, during which he pledged to bring back one million manufacturing jobs lost during the great recession of 2009. Is this focus on manufacturing a nostalgic bid for middle-class American jobs that are gone for good? One prominent stream of thought was that the decline in manufacturing in the United States was part of a natural evolution from agriculture to manufacturing to services (Delong, 2017). This paper argues that rebuilding manufacturing in America, especially advanced manufacturing, is critical to the ability of the economy to grow, deliver family sustaining jobs, and address key national needs like environmental sustainability and national defense.

\section{Manufacturing Drives Overall Economic Innovation}

Conventional wisdom is that manufacturing is an industry of the past and not innovative. However, manufacturing companies account for 67 percent of all private sector research and development (R\&D) spending in the United States (NSB, 2016). Simple math has meant that the decline in U.S. manufacturing has been associated with a decline in the U.S. share of world-wide spending on R\&D from 35 percent in 2003 to just 27 percent in 2013. Still, many scholars have posited that globalization would allow the U.S. economy to design next generation products while using off-shore manufacturing to maximize profits and U.S. economic growth (Jorgenson \& Timmer, 2011). But closer analyses have revealed outsourcing of production has led to an outsourcing of innovation. For example, U.S. companies first outsourced production of rechargeable laptops and their batteries to East Asia. East Asian countries took advantage of their expertise to create the next generation of rechargeable batteries-leaving the United States behind in the critical green economy technology of energy storage (Ezell \& Atkinson, 2011). Harvard professors Gary Pisano and Willy Shih warn that there are many instances where production processes are not mature or in which the process of production is closely tied to innovation. For these products, including many critical twenty-first century technologies like medical devices, robotics, and advanced life sciences, a strong manufacturing base is necessary for American leadership in innovation (Pisano \& Shih, 2012). 


\section{Challenges to Innovation and Productivity}

Ball State professors Michael Hicks and Srikant Devaraj have advanced a view that manufacturers are becoming more productive, able to produce similar levels of output with fewer workers and more robots (Hicks \& Devaraj, 2015). However, most of the reported productivity growth in manufacturing since 2000 is an anomaly, a result of the way the government calculates the value added of increasingly higherpower computer chips. From 2000 to 2015, the government reported that real output in the computer and electronic products sector grew by 222 percent, while the other eighteen manufacturing subsectors have seen their real value-added increase by just 7 percent (Houseman, et.al., 2014).

Case Western Reserve University economist Susan Helper offers a useful perspective on the state of manufacturing today (Helper \& Tucker, 2016). The United States has had more difficulty maintaining its share of production for non-durable commodity goods like textiles, apparel, and paper products. (A resurgence of plastic manufacturing driven by the oil boom is a notable exception). In contrast, the United States has maintained a competitive edge in a constellation of major capital-intensive durable products industries, especially transportation equipment (vehicles and aerospace), which have led the manufacturing recovery. Each of these industries depends on an ecosystem of suppliers, including fabricators of components which remain viable in the United States due to their proximity. In general, the ability of both manufacturers and their suppliers (large, medium, and small) to improve their productivity is a central and yet often overlooked determinant of manufacturing revitalization. Entire manufacturing subsectors are in fact in competition globally with other similar sectors located in Asia and Europe (Helper, et.al., 2012). As the world's second largest manufacturing nation, the United States faces international competitors like China and Germany who are investing in national industrial policies, like Made in China 2025 and Industry 4.0, that are focusing on capturing next generation products and components as well as integrating productivity-enhancing production techniques, from 3-D printing to internet of things optimization.

\section{Manufacturing Meets Key National Needs}

Beyond general technological innovation, manufacturing plays a critical role in meeting major national needs. One underappreciated area is the response to climate change, including the production of materials for renewable energy production and distribution, as well as manufacturing of energy efficient goods, such as vehicles, construction materials, and appliances. Indeed, a 2012 estimate from the Brooking Institution found that clean energy jobs are three times as manufacturing intensive as the rest of the economy (Muro, et.al., 2016). When it comes to national security, a major 2018 review concluded that the decline in U.S. manufacturing posed multiple strategic risks) (US DOD, 2018). These included a shrinking pool of suppliers that has left the military reliant on fragile or sole suppliers for critical components needed to maintain current equipment and scale up in times of conflict. Moreover, the military now depends on strategic competitors, like China, critical components like electronics and rare earth metals (whose production has nearly ceased in the United States) (Yudken, 2010). And the military is critically worried about the ability of the U.S. economy to develop next generation technologies, like 3D printing and lightweight metals, that are critical to U.S. and domestic production (US DOD, 2018).

\section{Economic Growth}

Economic developers have long treasured manufacturing facilities, because their impact reaches far beyond those directly employed. Manufacturing employers require a wide number of "inputs"-materials, components, devices - which they transform and to which they add value. The Manufacturing Alliance for Production and Innovation estimates that as production ripples throughout the economy, it creates an additional $\$ 1.33$ in the economy for each dollar of production, a far higher multiplier than those contributed by other sectors like health care $(\$ 0.72)$ and retail $(\$ 0.66)$ (Manufacturing Institute \& MAPI, 2012). Manufacturing's smaller economic footprint has left the U.S. with 11 percent of this economically beneficial activity contributing to our GDP, as compared to 21 percent of GDP in Germany and Japan, which has in turn contributed to a trade deficit in goods of $\$ 891$ billion in 2018 (US Census Bureau, 2019). Advanced, developed nations typically make and create capital goods, which are then exported to 
developing nations, but the United States has steadily increased its consumption of imported consumer apparel, electronics, and industrial components, with no corresponding increase in advanced manufactured goods.

\section{Manufacturing Is Still a Critical National Source of Jobs}

Above all, manufacturing has been valued as a source of good paying jobs for communities. Figure 1 looks at the level of manufacturing employment since 1990. Manufacturing jobs remained basically steady between 1990 and 1999 at seventeen million jobs, but manufacturing employment plummeted by 5.8 million jobs (a 33 percent decline) in the first decade of the twenty-first century. Many manufacturing employers closed up shop, shutting down 56,000 establishments from 2000 to 2010 (Bureau of Labor Statistics, 2018). Small establishments with fewer than forty-nine employees $(37,000$ establishments closed) were hurt the most, and this crucial subset has yet to bounce back (Bureau of Labor Statistics, 2018). In contrast, during the recent recovery (2010-2016), manufacturing has grown alongside the rest of the economy. Manufacturing companies added 1.4 million jobs from January 2010 to April 2019, with more jobs added in 2018 than any year in the previous three decades. This period has shown that the goal of bringing manufacturing back from overseas can be more than a mere campaign talking point. In 2017, a record 171,000 jobs were reshored into the United States, either from foreign direct investment in U.S. factories or from U.S. companies moving production back to American soil (Moser, 2018). When companies looked more closely at the hidden costs due to poor quality and shipping, they found that 55 percent of manufactured goods could be produced more cheaply in the United States compared to only 3 percent based on the sticker price alone. (Moser, 2015).

\section{FIGURE 1 \\ MANUFACTURING JOBS (1000s)}

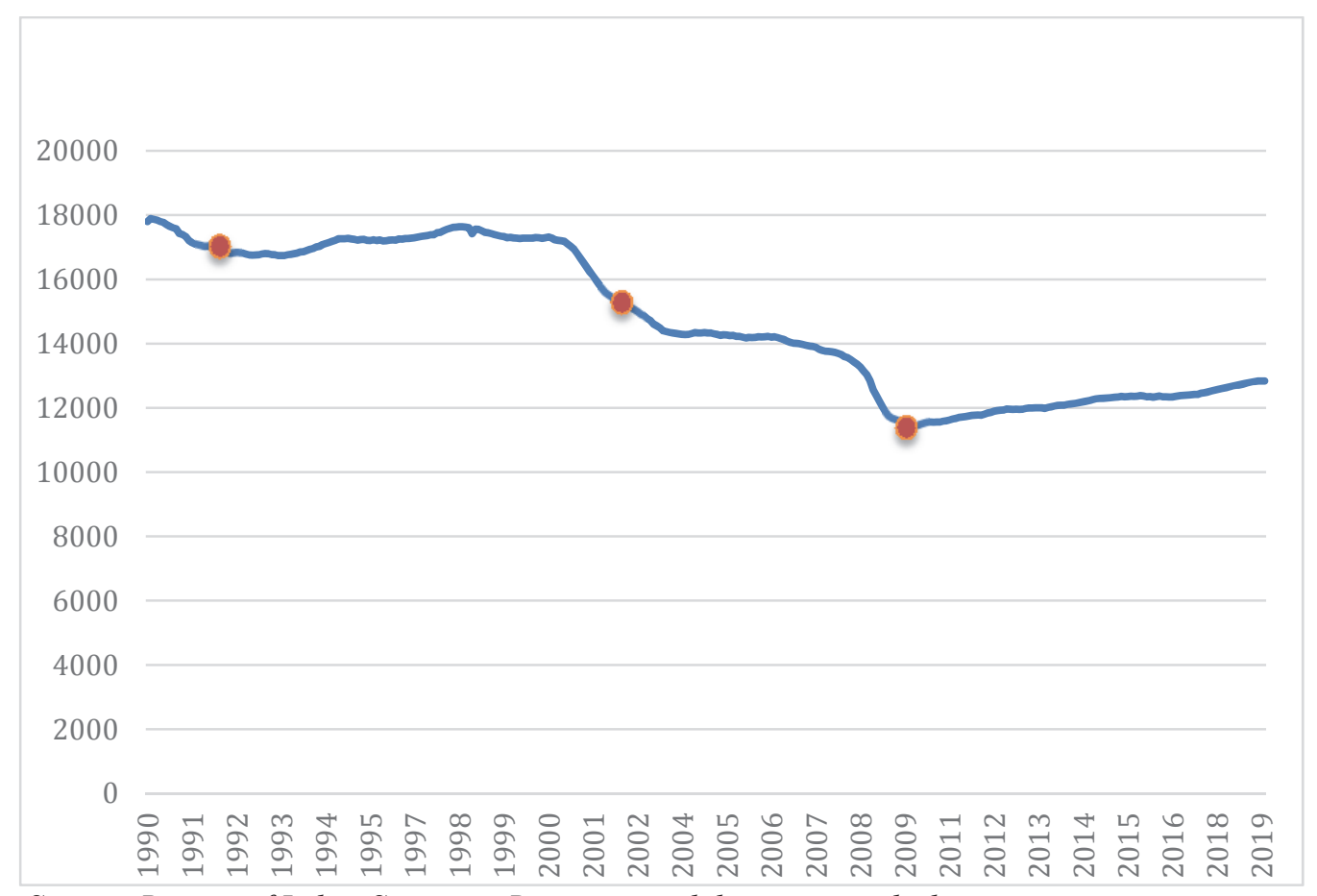

Source: Bureau of Labor Statistics. Recession end dates are marked in orange.

Manufacturing employment is also larger than any other sector except for health care, retail and accommodation, and food services. While there are manufacturing jobs in every state, with California and 
Texas having the most industrial jobs, there are distinct regional elements. Table 1 lists the top fifteen states in terms of manufacturing density, all of which are in the Midwest or Southeast. This first six years of the manufacturing recovery contributed to a more geographically concentrated U.S. manufacturing industry - the states with the greatest density of manufacturing added the most jobs (shaded in green). This stage of the manufacturing recovery was heavily reliant on the rebound of the North American auto industry, a mega-cluster that spans from Michigan through Mississippi. In the last two years, the manufacturing recovery has become more diffuse as the recovery has spread to additional sectors. (See table for full data in the appendix). Manufacturing's character varies significantly by region, with the industrial Southeast moving from furniture and textiles to transportation equipment, a cluster of agriculture states in the Midwest that specialize in food processing, and eastern and western states that have a greater concentration in technology intensive manufacturing, like chemicals and computers and electronics.

TABLE 1

TOP FIFTEEN STATES BY MANUFACTURING DENSITY, 2019

\begin{tabular}{|c|c|c|c|c|}
\hline \multirow[b]{2}{*}{ State } & \multicolumn{3}{|c|}{ Change in Employment } & \multirow{2}{*}{$\begin{array}{c}\text { Manufacturing } \\
\text { Jobs as Percent } \\
\text { of Private } \\
\text { Sector Jobs } \\
\end{array}$} \\
\hline & $\begin{array}{c}\text { Jobs Lost } \\
\text { 2001-2010 }\end{array}$ & $\begin{array}{c}\text { Job Gains } \\
\text { 2010-2016 }\end{array}$ & $\begin{array}{c}\text { Job Gains } \\
\text { 2017-2019 }\end{array}$ & \\
\hline Indiana & -200 & 79 & 25 & $19.8 \%$ \\
\hline Wisconsin & -159 & 50 & 2 & $18.5 \%$ \\
\hline Iowa & -50 & 10 & 19 & $17.2 \%$ \\
\hline Michigan & -392 & 143 & 41 & $16.6 \%$ \\
\hline Alabama & -100 & 29 & 6 & $16.1 \%$ \\
\hline Mississippi & -75 & 4 & 5 & $15.9 \%$ \\
\hline Kentucky & -96 & 38 & 9 & $15.6 \%$ \\
\hline Arkansas & -78 & -6 & 13 & $15.6 \%$ \\
\hline Ohio & -386 & 77 & 12 & $14.6 \%$ \\
\hline Kansas & -40 & 3 & 7 & $14.4 \%$ \\
\hline South Carolina & -124 & 37 & 13 & $14.2 \%$ \\
\hline Tennessee & -179 & 46 & 13 & $13.4 \%$ \\
\hline Minnesota & -106 & 28 & 4 & $12.6 \%$ \\
\hline South Dakota & -7 & 5 & 5 & $12.6 \%$ \\
\hline
\end{tabular}

Source: Authors' analysis of Bureau of Labor Statistics data.

As a share of jobs, manufacturing is particularly vital to small towns. Figure 2 shows an analysis of the share of private sector jobs found in the three types of counties defined by the Census Bureau: rural (100 percent rural), mostly rural (50 to 99 percent rural), and urban (less than 50 percent rural). Manufacturing is now most vital to mostly rural communities in these manufacturing states, where it makes up one-in-four private-sector jobs, as compared to either strictly rural or urban areas. These are places like tiny Price County, Wisconsin (population 13,000) in the rural Indian Head region, where manufacturing comprises 44 percent of private-sector payrolls. Price County is the birthplace and home of 
Phillips Medisize, a multinational corporation that provides advanced molding and engineering services for the medical device and specialty commercial sectors.

\section{FIGURE 2 \\ MANUFACTURING SHARE OF PRIVATE SECTOR JOBS, 2016}

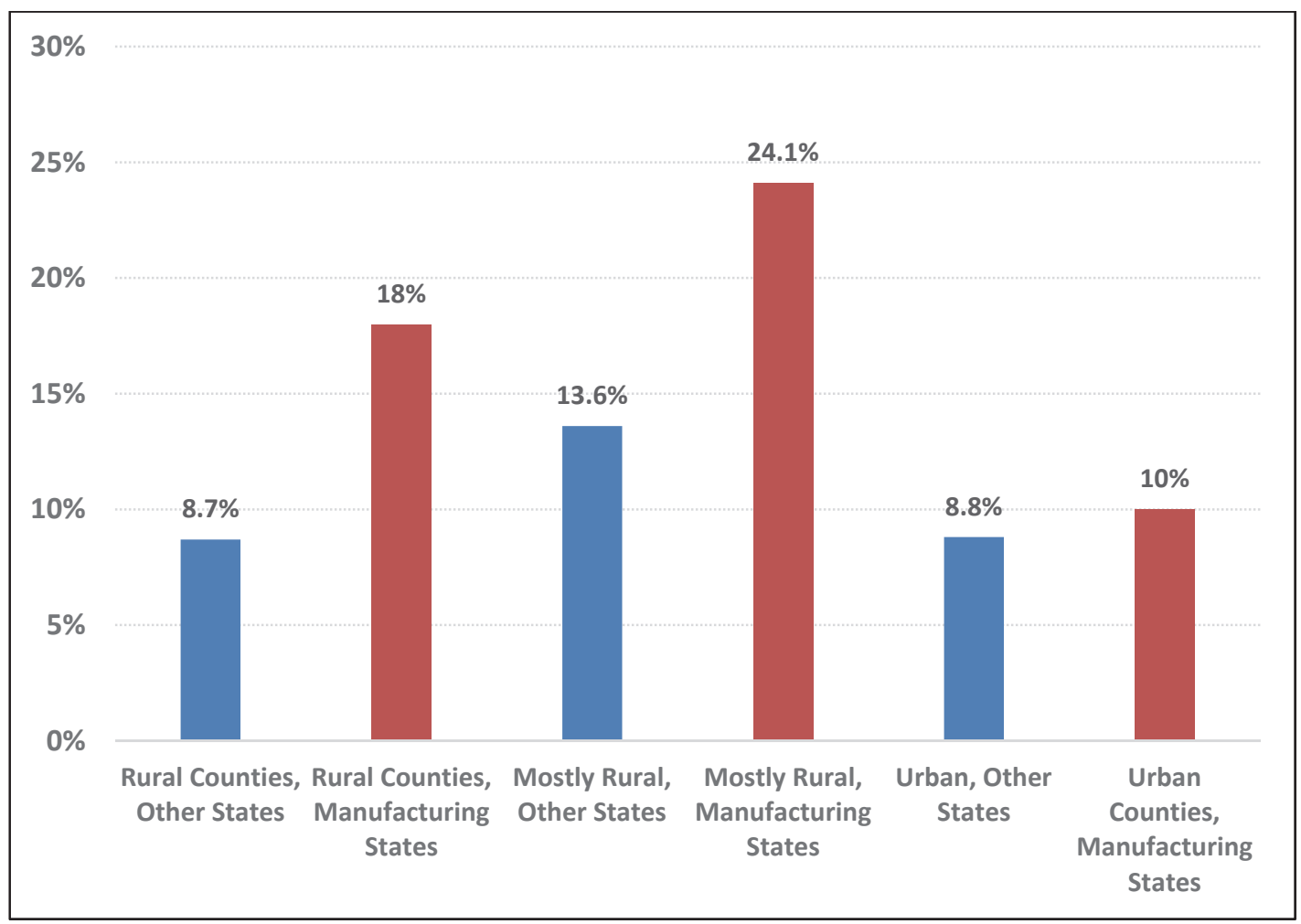

Source: Authors' analysis of Bureau of Labor Statistics and Census Bureau data.

With an average pay of $\$ 64,395$ per year, manufacturing continues to pay better wages than the sectors of retail trade, health care and social assistance, and accommodation and food services - all of which have in the last fifteen years surpassed manufacturing as an employer of Americans. (Stettner, Yudken and McCormack, 2017) Moreover, manufacturing employs a large number of individuals without a four-year college degree, and manufacturing jobs pay better than positions available in other industries for workers with that level of education. Despite the major changes rocking manufacturing, Figure 3 shows that the weekly wage for manufacturing workers with some college has remained consistently ahead of that for other industries - a separation of about $\$ 150$ a week. Workers with less than a four-year college degree represent about 60 percent of the workforce.

\section{Recruiting the Workforce of Tomorrow}

With one of the oldest workforces in the economy, manufacturing has two major workforce challenges: a pipeline problem, and a skills gap problem. Often described as the same challenge, these in fact are two different problems. Deloitte and the Manufacturing Institute went so far as to predict a gap of 2 million manufacturing workers over the next ten years. However, in all but six months of the past five years, there were more job openings than hires - meaning that manufacturers were unable to fill jobs and positions remained open (Manufacturing Institute \& Deloitte, 2015). The shortage of skilled workers is a part, but not all, of the workforce challenge facing manufacturing. One detailed study of core production workers indicates that between 16 percent and 25 percent of manufacturing establishments have longterm vacancies, which indicates a genuine shortage of qualified workers (Weaver \& Osterman, 2017). 
While the existence of the skills gap in manufacturing is a topic that has divided scholars, there is solid evidence that manufacturing workers are not having as easy a time hiring as they once did. Figure 4 displays that in all but six months of the past seven years, there were more job openings than hiresmeaning that manufacturers were unable to fill jobs and positions remained open; this is a reverse of the prior period, when there were more hires than openings each month.

\section{FIGURE 3 \\ WEEKLY WAGE, MANUFACTURING VERSUS NONMANUFACTURING, FOR WORKERS WITH LESS THAN A FOUR-YEAR COLLEGE EDUCATION, 1990-2016}

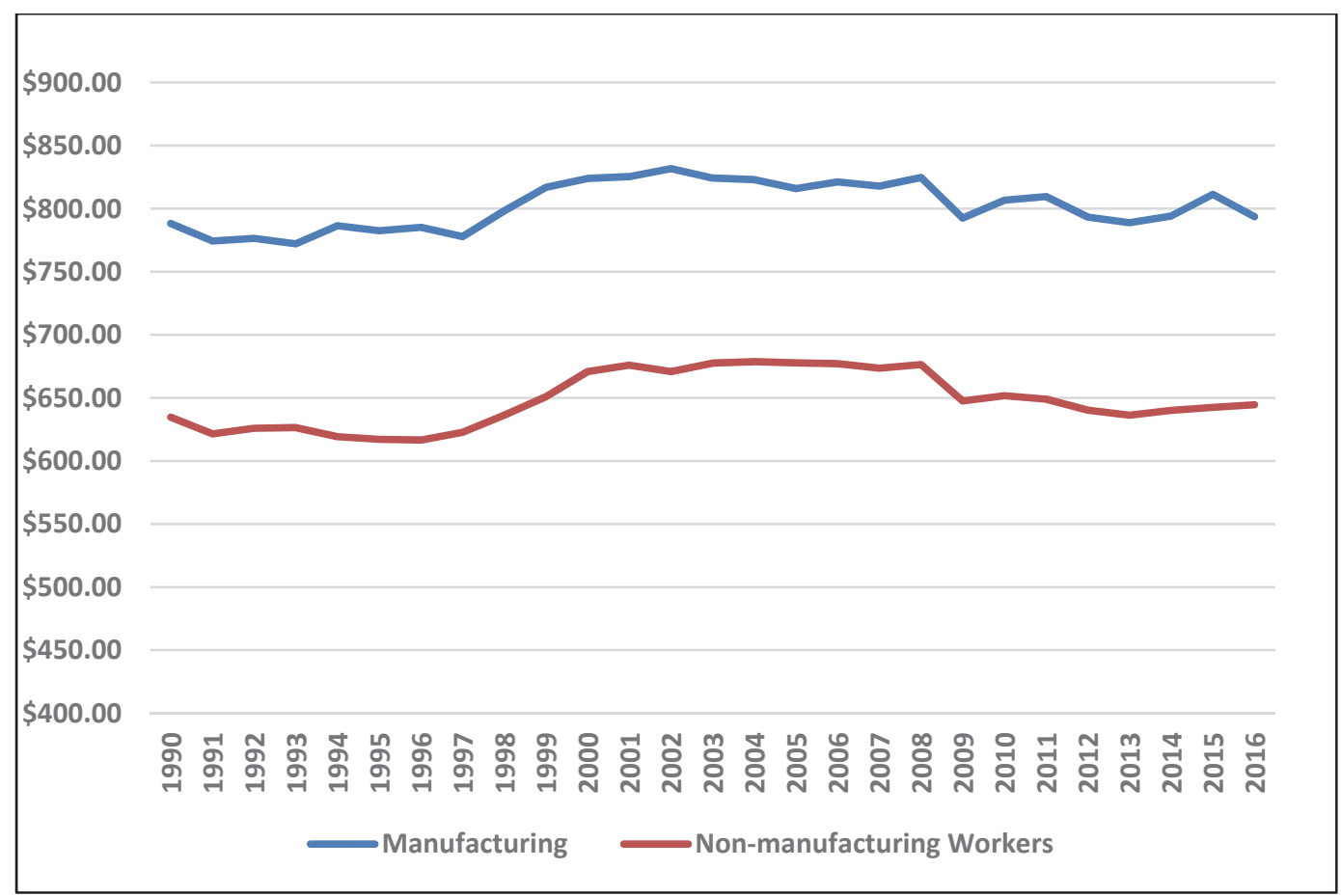

Source: Authors' analysis of data taken from Sarah Flood, Miriam King, Steven Ruggles, and J. Robert Warren. Integrated Public Use Microdata Series, Current Population Survey: Version 4.0. [dataset]. Minneapolis: University of Minnesota, 2015, http://doi.org/10.18128/D030.V4.0.

Attracting a new generation of workers into manufacturing is complicated by the variability of job quality, and the shrinking pay advantage. A recent analysis found that manufacturing workers still earn 13.0 percent more than similarly situated workers in other sectors, but this wage premium is down twenty-five percent from the 1980s. Of critical concern, there is significant variation in the quality of frontline production operations (Mishel, 2018). Temporary help agencies now employ more production workers than workers from any other industry, and production workers employed by temporary firms earn significantly less on average (\$12.81 per hour) than other production workers $(\$ 17.49)$ (Mishel, 2018). One out of three production workers had wages so low during the 2009-to-2013 period that they were forced to rely on some form of public assistance (food stamps, health care, tax credits) to make ends meet (Jacobs, et.al., 2016). The sharp decline in unionized workplaces in steel, auto, machinery, and other industrial sectors brought the union coverage rate in manufacturing down to just 9.6 percent in 2010, only slightly better than the national rate of 7.3 percent among all private-sector employers. This had the biggest impact in the Industrial Heartland, where union coverage dropped from 28.4 percent of manufacturing workers to 14.5 percent of workers from 2010 to 2016 (Stettner, et.al., 2017).

Manufacturing companies cannot expect workers to jump into manufacturing careers today if they do not pay more than in other fields that demand less from workers and often require less skill. Some have 
argued that better wages would solve manufacturing's workforce problems by increasing labor demand (Carter, 2012). Raising wages alone will not solve skills shortages; however, better wages will make it more likely for workers to make the investment in developing the skills factories need. Manufacturers will need to find ways to pay higher wages in order to make manufacturing jobs attractive to the next generation of workers.

FIGURE 4

MANUFACTURING JOB OPENINGS AND HIRES, 2000-2019

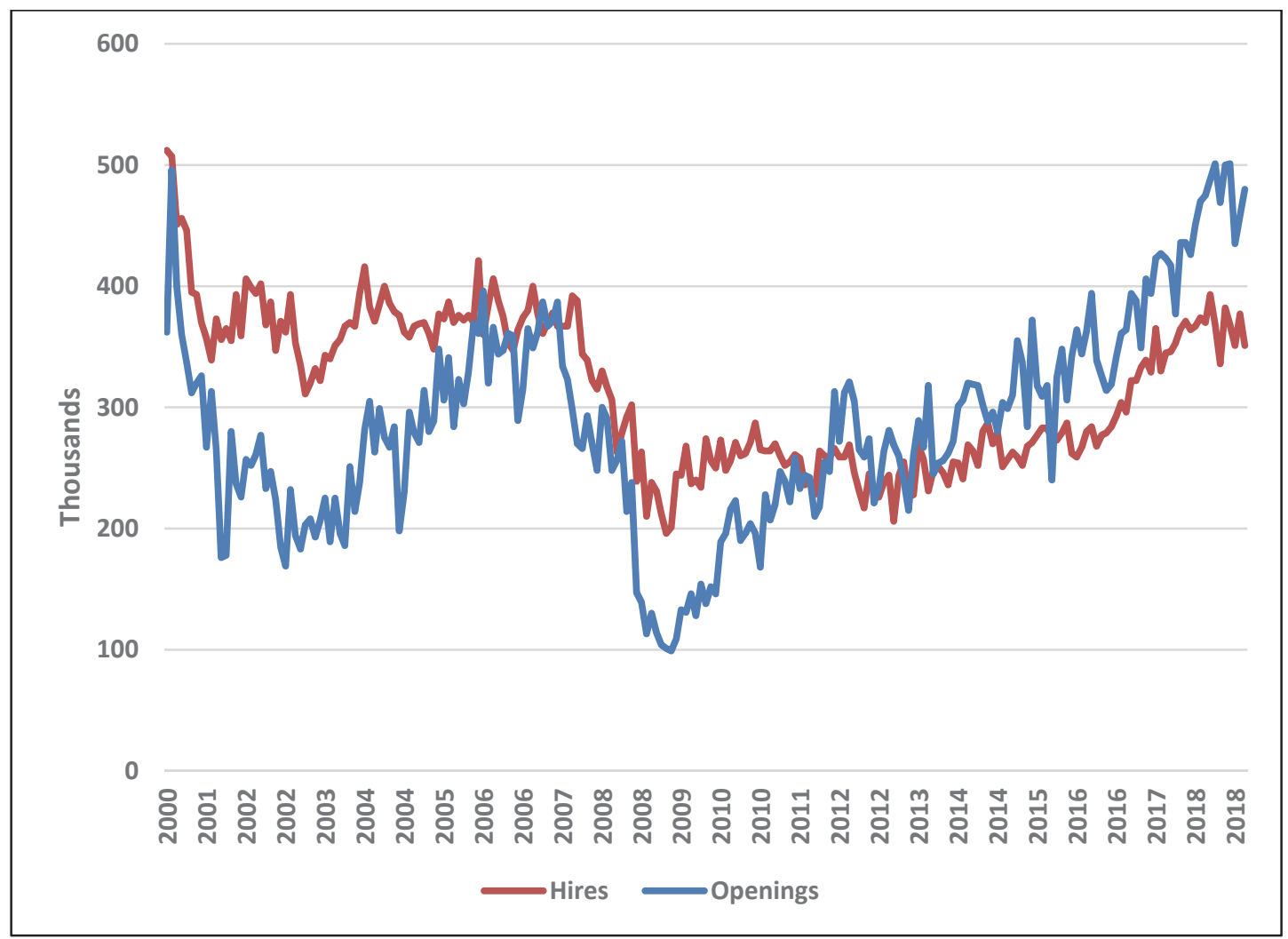

Source: Bureau of Labor Statistics, Job Opening and Labor Turnover Survey.

As the manufacturing sector strives to restock its workforce as baby boomers retire, it will need to develop a diversity that is reflective of the racial and gender diversity of today's economy. Participation by African American and Hispanic people working in manufacturing increased only modestly over the past twenty-five years. For example, African Americans represent 10 percent of manufacturing workers but a 12 percent share of the overall workforce (Stettner, et.al., 2017). Strikingly, women make up 47 percent of the total U.S. workforce but they fill only 29 percent of manufacturing jobs (US DOL, 2017). In recruiting a new generation into manufacturing, the industry will have to reverse negative images of factories of manufacturing as dirty and dangerous, images born out of a generation of deindustrialization, especially in urban inner cities like Milwaukee and Chicago. While 64 percent of Americans think a strong domestic manufacturing sector is important to the nation's economy, only 37 percent think that manufacturing is a good career for their children (AAM, 2016). While there are new efforts, like National Manufacturing Day, robotics competitions, and makers clubs, aimed at changing these perceptions, only 13 percent of manufacturers surveyed frequently recruit at high schools (Sirkin, et.al., 2013).

The data above should inform the kind of manufacturing revitalization policy needed in America. With manufacturing productivity lagging, there's a clear need to prioritize higher levels of innovation 
within existing manufacturing companies and greater leadership in twenty-first-century products like those related to environmental sustainability. Moreover, the tremendous regional variety in manufacturing calls for policies that gives states and regional governments the tools to address the needs of distinct manufacturing economies. Lastly, policy should train its attention on efforts to recruit a new generation of industrial workers and maintain close attention to job quality issues that may determine the success of such efforts.

\section{REGIONAL INDUSTRIAL REVITALIZATION MODEL}

After decades of deindustrialization and disinvestment, many industrial communities in America's Heartland continue to suffer from economic hardship. As long-time Youngstown State University business professor and researcher John Russo observes, "Deteriorating factories, empty parking lots, dilapidated housing, and vacant lots, all bear witness to the continuing material and social costs of economic restructuring" (Russo, 2017). While the urban cores of some cities (e.g., Pittsburgh, Milwaukee) have enjoyed phoenix-like recoveries, surrounding rural, suburban, and inner-city areas remain plagued by employment and population declines, high levels of poverty, poor schools, increasing violence, social dysfunction, and environmental degradation. Despite well-intentioned federal and state efforts, the nation's poorly funded patchwork of economic development, workforce assistance, and safety-net programs have had limited success helping these former industrial communities fully recover from the hardships and disruptions stemming from trade agreements, offshoring, technology change, and government policy shifts, among other causes.

Conventional wisdom has tended to discount a return of manufacturing to our shores as a viable economic recovery strategy for these communities. We argue otherwise. Our work has shown that revitalizing and restoring America's manufacturing sector can be key to their economic revival, rebuilding the American middle-class, and creating opportunities for minorities and low-income families to increase their social and economic mobility. Specifically, we propose a public policy agenda and strategy to achieve the following goals:

- Harness the renewal of American manufacturing to the economic recovery of "left-behind" rural, urban, and suburban communities in America's industrial heartland and around the nation, which have been hurt by globalization, technology change, government policy shifts, and other economic shocks. In particular, we reaffirm the importance of rebuilding a globally competitive, innovation-based advanced manufacturing sector in the United States.

- Provide a framework and template for state and local governments working with nongovernmental stakeholders to build a high road industrial commons, which links manufacturing revival to regional economic revitalization, helping distressed rural and urban communities in the nation's industrial heartland make the transition to economic prosperity.

\section{A High Road Industrial Commons}

Industrial advocates and policy experts assert that rebuilding the nation's industrial commons is necessary to enable a robust revival of American manufacturing driven by innovation and advanced technologies. Harvard Business School professors Gary Pisano and Willy Shih introduced the term to characterize the resources and capacities required to foster innovation and a strong advanced manufacturing base. It refers to research and development and manufacturing infrastructures, including the know-how, process development skills, and engineering capabilities - as well as access to suppliers of advanced materials, tools, production equipment, and components - needed to retain, restore, and grow new industrial capacity in specific sectors and geographical locations (Pisano \& Shih, 2009).

However, robust high-tech industrial commons alone will not ensure that gains from reinvigorated industrial growth will benefit America's most economically distressed communities and vulnerable workers. Proponents of an innovation-led manufacturing revival, such as the Information Technology and Innovation Foundation (ITIF), warn that, without appropriate actions, industrial heartland communities hurt by the loss of U.S. manufacturing could still be left out of any new advanced manufacturing boom. 
ITIF cautions that a "rising tide doesn't automatically lift all regional boats" (Atkinson \& Ezell, 2017, p.18), and former White House advisor Jim Pinkerton argues that "we can't live with . . . a country in which whole states are left behind, in the dust" (Atkinson \& Ezell, 2017, p.18). Similarly, McKinsey Global Institute analyst Sree Ramaswamy believes addressing dislocation should be a priority for revitalizing American manufacturing. He calls for place-based strategies to invest in manufacturing communities, mitigate trade dislocation, and address the needs of older workers and the problem of declining mobility (Ramaswamy, 2017).

Instead, we call for a high road commons which advances activities and features that promote globally competitive, innovation-driven, advanced manufacturing while also promoting the retention, restoration and creation of family-sustaining jobs, especially in economically distressed communities. The activities of a high road industrial commons also make inclusiveness, equity, and social mobility primary criteria and target their benefits to all "left-behind" communities and workers regardless of race, gender, or geographic locale.

\section{Strategy for Manufacturing and Regional Economic Recovery}

To meet the challenge of building high road industrial commons, we propose here a proactive strategy that brings together public, private, and civil sector stakeholders to forge a link between manufacturing revitalization and the regional economic recovery. As the model shown below shows, the strategy includes two national drivers, and four regional drivers, which, taken together, foster the retention, restoration, and growth of America's industrial commons.

\section{STRATEGY FOR MANUFACTURING REVIVAL AND REGIONAL ECONOMIC RECOVERY}

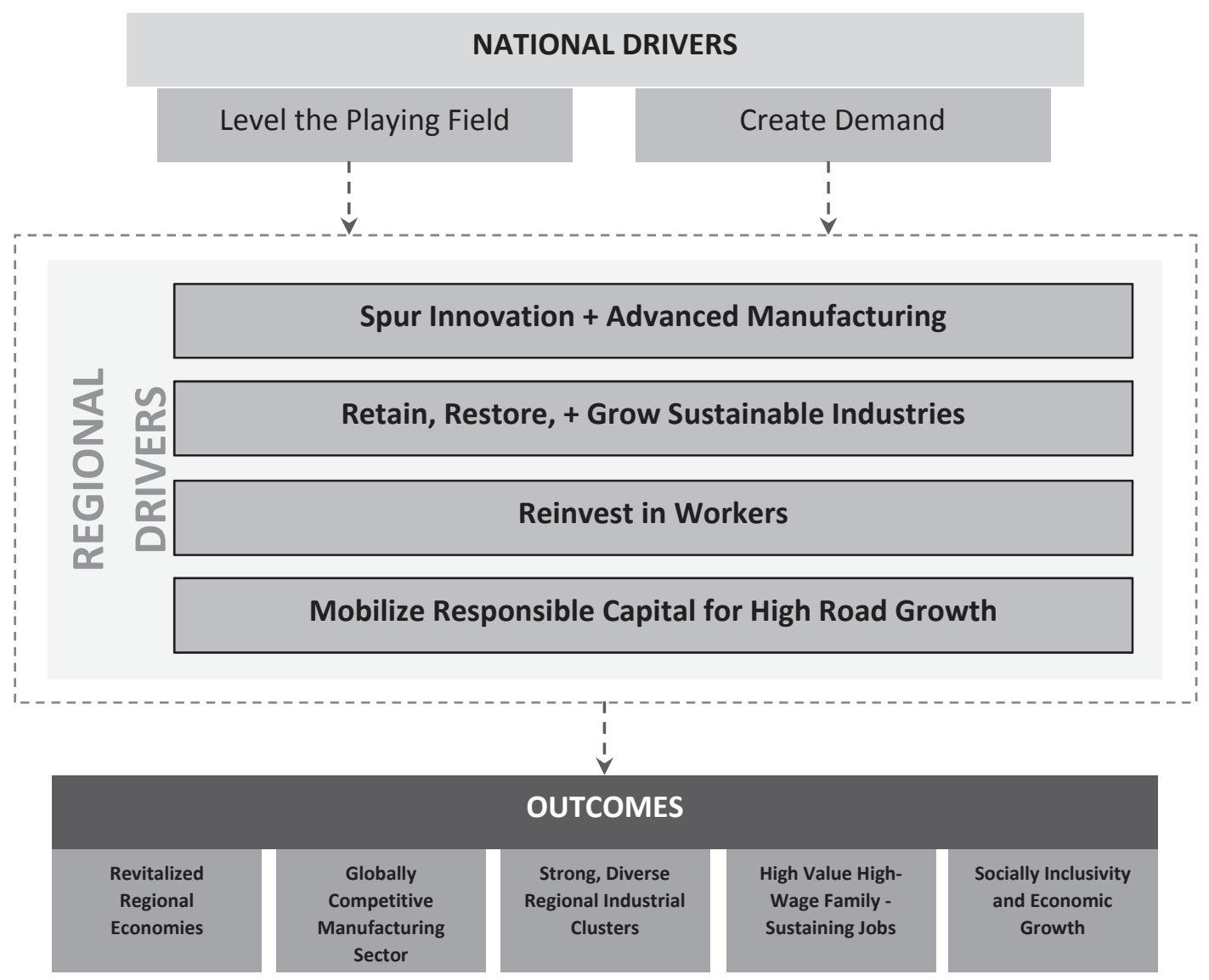


At the national level, we recognize the importance of federal policy drivers to enable sustained success of the strategy applied at the regional and local levels. At the same time, there is much that state and local governments can do to support, supplement, and extend the national drivers to benefit their jurisdictions such as state Buy America provisions (Stettner, et.al, 2019). In particular, the federal government should:

- Level the playing field for U.S. manufacturers in international and domestic markets. Key measures of this driver include fair trade agreements, enforceable labor and environmental standards, the enforcement of unfair trade practices, addressing currency overvaluations, and tax and financial reforms to reduce corporate incentives to move production offshore.

- Create and expand demand for U.S.-made goods at home and abroad. This driver would present new market opportunities for U.S. producers, and ensure that U.S. manufacturers in fact benefit from these opportunities. The former includes government investments to address major national needs (for example, infrastructure, clean energy, affordable housing). The latter refers to domestic content requirements in government procurement (for example, Buy America) and encouraging consumer purchasing of U.S.-made goods.

Since there already is an extensive relevant literature on these issues, especially on trade, tax, and currency measures, which have long occupied much of manufacturing policy debate, we do not discuss them here (Block, 2017). Our main focus is on four major drivers of a manufacturing-led economic recovery at the regional, state, and local levels. While these drivers have distinct characteristics and elements, they must be understood as operating together. That is, there are necessary overlaps and synergies across the drivers. The workforce reinvestment and capital strategies drivers are especially cross-cutting - their applications help enable and enhance the impacts of the other drivers (for example, both capital availability and a skilled workforce are critical to advanced manufacturing innovation).

\section{Driver 1. Spur Innovation and Advanced Manufacturing}

Any viable national strategy to restore American manufacturing and support the recovery of "leftbehind" industrial communities must start with measures that strengthen the nation's innovation ecosystem. These measures should not only support the growth of America's unequaled basic and applied research system. They need to advance the development of advanced manufacturing technologies, processes, and capabilities, to facilitate the transition of promising early-stage technological inventions into scalable, cost-effective, and high-performing domestic manufacturing enterprises (Deloitte, 2017). We are not just talking about the restoration of traditional manufacturing bases, but the successful growth of new, cutting-edge industrial sectors, often built upon the legacy of earlier industrial competencies.

There are notable examples of manufacturing revivals driving successful regional and local economic recoveries building on past manufacturing legacies. For example, Pittsburgh, Pennsylvania, and Syracuse and Rochester, New York, have been called "phoenix" cities, rising up from the ashes to be leaders in innovation and advanced technology (Christopherson, 2009). A number of communities, such as Akron, Ohio (around polymers) and Albany, New York (around semiconductors) also have transitioned from traditional manufacturing industrial bases, to globally competitive economies built around innovation and "smart" manufacturing (van Agtmael \& Bakker, 2016). To achieve similar successes, state and local governments should adopt the following measures:

Similarly, the Heartland communities we visited in our summit tour embrace manufacturing as part of a high-tech future, rather than a nostalgic look to the past. In Cleveland, U.S. Senator Sherrod Brown stated "To call us Rust Belt demeans our work and diminishes who we are. Today's factories in Ohio and around the country are not rusting, they're innovative, they're high tech plants" (Brown, 2018). Brown cited Cleveland's ArcelorMittal steel mill as the first plant in the world where one person-hour of work creates one ton of steel (Acelor Mittal, 2019). Leaders in all three cities called for increased publicprivate partnerships to bolster advanced manufacturing clusters, like the Advanced Robotics for Manufacturing Institute at Carnegie Mellon University (one of fourteen institutes funded by the new Manufacturing USA program) to firmly position the Industrial Heartland as the manufacturing hub for a new generation of products. If there is one critique of federally funded advanced manufacturing efforts, it 
is that they are too focused on technology development and not enough on how to create jobs and educate the local workforce on the skills needed for high tech manufacturing. To promote successes similar to those above and address shortcomings in federal and state policies, to foster a strong innovation commons regionally and national, we propose the following measures:

- Support regional innovation and advanced technology $R \& D$ institutions. Many state and local governments promote innovation and advanced technologies to grow new, competitive industrial sectors and foster regional growth and employment. This includes continuing and expanding their investments in public and private research universities and cooperative R\&D centers and partnerships. The latter bring together multiple research activities to help dissolve the barriers between scientific disciplines and between scientific research, engineering applications, and product and process commercialization (NRC, 2013). They also refer to joint R\&D efforts (consortia and networks) of multiple firms and other research institutions. States also should also encourage and increase their support for manufacturing incubators, often associated with universities, which provide environments for developing startups and innovation concepts without the short-term pressure for generating revenues in the marketplace (Goldin Peiser \& Peiser, 2015).

- Support state and local advanced manufacturing $R \& D$ investment sources and incentives. States should continue and expand support for programs and mechanisms to leverage federal and private sector investments in private and public-sector R\&D institutions and initiatives. These include $R \& D$ tax credits for private sector investments in innovation, especially for advanced manufacturing technologies (all but twelve states have a form of these credits) (Intrepid Advisors, 2016), and innovation vouchers, which are grants to small- and mediumsized firms to enable them to access outside R\&D resources (Connecticut, Iowa, New Mexico, Rhode Island, and Tennessee and other states have had success with them). States also should support investment programs that fund state-based, technology-oriented economic development initiatives, favoring early stage technology development. For example, Ohio's Third Frontier program provides funding to state-based technology-oriented companies, universities, and non-profit research companies, to encourage the growth of new companies, industries, products, and jobs.

- Promote regional multi-firm and multi-stakeholder innovation clusters in advanced manufacturing and related sectors. Innovation clusters are collaborative networks of multiple stakeholders - usually for a specific sector and in geographical proximity - that can include manufacturers, supplier chains, government agencies, universities, research institutes, community colleges, vocational institutions, and other nongovernmental and not-for-profit organizations. States should continue and increase investments in the growth of innovation clusters focused on advanced manufacturing technologies, to foster the competitiveness of local industries, building on existing competencies (such as Toledo, Ohio's photovoltaics cluster built on its legacy of glass manufacturing) (NRC, 2013). States also should continue their matching investments for Manufacturing USA, a federal interagency-funded network of fourteen public-private regional institutes, led by the Commerce Department's National Institute of Standards and Technology (NIST). Modeled on Germany's successful Fraunhofer-Gesellschaft applied research system (Fraunhoffer-Gesellschaft, 2015), the program brings together academia, large and small companies, and government, emphasizing innovation, collaboration, and workforce education and training in advanced manufacturing areas (such as robotics, additive manufacturing, and lightweight metals) (Deloitte, 2017). ${ }^{1}$

- Support development of maker and co-working spaces. The urban "maker" movement of small producers designing, prototyping, and producing newly developed manufacturing goods has revived interest in urban manufacturing. The maker movement, which began with hobbyists, is a new source of product innovation and future manufacturing opportunities (Fallows, 2016a, b, c). "Makerspaces," a location where makers carry-out their work, are 
twenty-first-century machine shops equipped with 3-D printers, CNC machine tools, water jets, and the like, and support engineering-oriented pursuits such as electronics and robotics, as well as traditional activities such as metalworking and woodworking. In these spaces, startups develop their prototypes and can get assistance from other makers or manufacturing specialists to help them with product design and prototyping. Cities can provide facilities and funding for makerspaces where aspiring makers can invent and produce small batches of goods. They also can create and assist local branding organizations, like Made in NYC, that market locally produced products and provide business assistance to small urban manufacturers not typically reached by traditional manufacturing assistance programs (Made in NYC, 2019), and enact local zoning policies that preserve industrial spaces.

\section{Supportive Federal Policies}

Federal programs will play a central role in fostering manufacturing innovation and can work closely in partnership with these regional actions. A high priority is to make federal core institutional funding for Manufacturing USA institutes permanent, with prescribed levels of fund matching from private sector partners and/or state governments and a greater priority on connecting these new technologies to workforce and regional economic development strategies. Furthermore, the number of Manufacturing USA institutes should be expanded beyond the current fourteen to the originally planned forty-five institutes, including a greater focus on core manufacturing technologies like materials joining technologies. In addition, the institutes' workforce initiatives should be strengthened, and their workforce education and training components more fully integrated with their advanced manufacturing innovation activities. The embedding of MEP staff within each institute also should be formalized, to facilitate the diffusion of technologies and process developed at the institutes to America's SMM supplier base.

\section{Driver 2. Retain, Restore, and Grow Sustainable Industries}

States and municipalities have at their disposal policies, strategies, tools, and resources that reside not only in government programs, but also in their stakeholder communities to support and assist manufacturing revitalization and high-road economic recovery. They can also leverage the resources of multiple federal programs, such as the Department of Commerce's Economic Development Administration (EDA), the Appalachian Regional Commission, and the Department of Labor, to help them restructure and transition their industrial bases in response to economic shocks, such as trade impacts and policy shifts (e.g., defense downsizing, environmental regulations), recessions and natural disasters. All these federal programs rely on close partnerships with local and state entities. Leadership at the local and state level determines the success of efforts to steer economic development. In particular, states and localities should:

- Promote the establishment of, and strengthen existing, state-supported strategic early warning networks and business retention services. Many shutdowns can be averted with sufficient early warning, coupled with a well-organized and expedient business turnaround or buyout effort. A program should include early identification of firms at risk of layoffs, the use of feasibility studies to assess the needs and options for at-risk-firms, and the delivery of services, such as investment and financial restructuring, economic development and adjustment, and employment and training, to address the risk factors. Early warning and layoff aversion have a strong record of success in the retention of manufacturing businesses and saving jobs, with substantial public benefits (US DOL, 2012). The nation's most effective state program is Pennsylvania's Strategic Early Warning Network, spearheaded by the Steel Valley Authority (SVA). However, although mandated in the Workforce Innovation and Opportunity Act of 2014 (WIOA), many states at best give lip service to adopting layoff aversion and developing core turnaround capabilities. States should allocate more resources toward intermediating entities (such as SVA) to locate businesses in trouble, assess their retention potential, and provide services that enable companies to retain their workforce and 
turn things around. These must be hard-wired into the regular process followed by a state when they receive a notice of an impending layoff.

- Support state-level reshoring assistance and initiatives. Reshoring is the practice of returning overseas manufacturing facilities and assets back to U.S. locations. It also can refer to restoring the domestic sourcing of currently imported supply chain inputs for reshored original equipment manufacturers (OEMs). Reshoring decisions depend on companies having accurate information about the true, often hidden costs of overseas production. States should launch and support multi-faceted reshoring initiatives, such as state reshoring teams encompassing state agency leaders and service providers, state agencies refining and promoting tools that assess the offshore/onshore trade off (such as Reshoring Initiative (RI)'s online Total Cost of Ownership (TCO) calculator), prioritizing reshoring companies for receiving state financial assistance, and developing reshored supply chain capacity.

- Strengthen the competitiveness of small- and medium-sized manufacturers (SMMs) and U.S.-based supplier chains. Small- and medium-sized manufacturers (SMMs) comprise 99 percent of manufacturing establishments in the United States, employ over 70 percent of all manufacturing employees, and account for the large majority of new jobs created in manufacturing (US Bureau of Labor Statistics, 2018). SMMs form the backbone of America's supply chains and include all of today's small entrepreneurial manufacturing startups. However, they often lack sufficient financing, personnel, capacity, capital equipment, expertise, and experience to improve their competitiveness, in areas ranging from innovation and productivity improvement, to workforce recruitment and training, to business development and modernization, among other needs. States should continue, strengthen, and expand the active role they play in helping SMMs in multiple areas, which often entails working with federal partners (MEPs, Manufacturing USA institutes, and other programs ${ }^{2}$ ), universities, manufacturing associations and firms, nongovernmental service providers, and intermediating organizations. They also should join with federal agencies and private sector partners to strengthen and optimize regional-based supply-chains, which emphasizes managing the total supply chain for maximum value (Mahoney \& Helper, 2017, p.2; PA DCED, 2013). When supply chains are optimized, suppliers are treated as partners and allowed to contribute design and engineering ideas. It also entails close coordination of manufacturing capacity, production planning, and delivery schedules.

- Enact and strengthen state and local trade and demand creation measures. State and local governments can encourage in-state and in-country sourcing of products and services in their procurement. This includes reviewing their current procurement strategy and laws and strengthening their Buy America, Buy [State], and buy local provisions. They also need to invest in critical regional infrastructure and advocate for greatly increased federal investments in rebuilding the nation's infrastructure. Such investments not only increase the demand for domestic and regionally produced products and services, a well-developed infrastructure is a strong selling point for attracting new industry to an area (KRC, 2016). In addition, state and local government leaders can advocate for U.S. fair trade policies, by-passing state resolutions, establishing a state Fair Trade Office to provide SMMs access to U.S. unfair trade protections, and pushing their congressmembers to vote for better trade policies (KRC, 2016). New federal rules allow regional governments investing in mass transit to give optional points to bids that would spur regional manufacturing and local hiring. Jobs to Move America used this tool to turn Chicago's purchase of new subway cars into a major new railcar manufacturing facility, complete with an aggressive plan to ensure that residents in the heavily African American South Side neighborhood can compete for the facility's 200 unionized jobs (Shropshire, 2017).

- Strengthen multi-stakeholder, comprehensive regional and local economic assessment and strategic planning tools and capabilities. Effective revitalization strategies start with a 
regionally based planning process. The EDA's Comprehensive Economic Development Strategy (CEDS) engages local governmental and nongovernmental stakeholders in developing strategic blueprints for regional industrial recovery and economic transition (US EDA, 2015). This process depends on an accurate assessment and analysis of an area's economic and industrial assets, resources, opportunities, weaknesses, and other conditions important for formulating an effective recovery strategy. To complement the high-quality data available from federal statistical agencies, many state and local government agencies (for example, Pennsylvania's Department of Labor and Industry) also collect and make available data useful for evaluating regional and local needs and opportunities. State and local governments should strengthen their data, research, and analytical capacities, and make them more available to aid stakeholder-driven planning processes, which is needed to support regional manufacturing cluster development, early warning/layoff aversion, and reshoring strategies. Moreover, they should mine more obscure sources of data, such as licensing and tax records, to give a fuller picture of which types of establishments are changing and how that is impacting local workers.

\section{Supportive Federal Policies}

When it comes to manufacturing economic development and retention, the role of the federal policy is to provide communities with resources and challenge them to adopt best practices. A particular promising model along these lines is the Investing in Manufacturing Communities Partnership, which successfully challenged twenty-four regional areas to develop comprehensive economic development plans and mobilized thirteen federal agencies to support their implementation. The pilot was enacted into law through the FY 2019 Defense Bill and is awaiting an appropriation. Similarly, funding for the Manufacturing Extension Program should return to its historical norm of close to \$200 million annually. Lastly, while a new aspect of the WIOA law requires states to use a portion of rapid response dollars to prevent layoffs in ways similar to the Early Warning Network, the Department of Labor needs to give stronger guidance to states to use these dollars to provide effective business turnaround services to manufacturers at risk of closure.

\section{Driver 3. Reinvesting in Workers}

This driver would support the growth of robust, regionally based workforce education, training, and certification to help workers seeking employment to qualify for high-value, family-supporting jobs in manufacturing and emerging industries, while also building a high-skilled workforce to meet the needs of those sectors. America has a workforce "matching" problem. U.S. manufacturers complain about skills gaps, the difficulty finding workers with the skills they need. Yet, many Americans, especially in economically distressed, "left-behind" rural, urban, and suburban communities continue to struggle to find decent, family-supporting jobs. This includes disadvantaged youth; minorities and women; incumbent workers dislocated or threatened by offshoring and technological change, or by policy shifts (defense cuts, environmental regulation); and long-term unemployed workers. This is the real "gap" that needs to be bridged for America to grow a competitive twenty-first-century economy.

A stark example of this gap is Chicago, where there are 15,000 unfilled frontline production jobs and where one in three manufacturing workers are over the age of fifty-five in Chicago (Córdova, et.al., 2018). Meanwhile, one out of three young African-Americans are out of school or out work,_especially in south and west side neighborhoods where deindustrialization has sparked a decades long of depopulation and violence (Córdova, et.al., 2018). In Chicago and other cities, the training apparatus in high school and beyond to connect such disadvantaged youth to manufacturing careers has withered away-- the most recent available data from 2013 showed that Chicago Public Schools had only trained 118 young people to industry recognized credentials in manufacturing (Harris, 2014). These challenges have created an opportunity for organizations like Manufacturing Connect, OAI, and the Janes Addams Resource Corporation to develop prototype programs that recruit manufacturing workers from urban communities of color that have written off the sector after decades of deindustrialization. Successful new models like 
these point the way to reform America's fragmented, inadequately resourced, difficult to access, of limited scope, poorly targeted, and unevenly successful workforce system (CFR, 2016; Vijaya, 2010; Muro, 2016; Lake, et.al., 2014). There are multiple strategies to reinvigorate federal, state, local and private sector investments in the nation's workforce system.

- States and local communities should support and increase investment for regional multiemployer industry or sector partnerships. Industry or sector partnerships bring together multiple employers, labor and apprenticeship organizations, training providers, and other stakeholders around specific industries in a region, to address the workforce needs of employers and provide workers pathways to high-value, family-sustaining jobs (NGA, et.al., 2006). ${ }^{3}$ Industry partnerships are especially valuable strategies for SMMs, which because of their size and limited resources find it difficult to implement effective workforce training programs (NSC, 2017). The drafters of WIOA made sector partnerships a required activity for states and local workforce boards (NSC, 2017), and many states have adopted sectorbased approaches to bridge the gaps between education and training programs and the skill needs of their main industries. WIOA, however, does not provide any dedicated resources to support these critical partnerships with industry and overall funding for WIOA has declined by 43 percent since 2001 (NSC, 2017). States and local governments should increase public resources and incentivize private resources for sector initiatives. This includes increasing collaboration among state agencies to produce and use timely, accurate labor market information, provide up-to-date analysis of industry sectors, and support strategic planning that meets worker and employer needs. They also should provide expertise to support, sustain, and expand sector initiatives (NGA, et.al., 2006), support standardized training and certification programs at the local, regional (or even national) level, to build credibility for certifications and portability (Duesterberg, 2016), and establish tax credits to support multiemployer industry partnerships.

- States should work with industry and educational institutions to support and replicate best practice apprenticeship training programs. Apprenticeships combine paid-on-the-job training and related classroom instruction to obtain workplace-relevant knowledge and skills leading to an industry recognized credential. Apprenticeship programs improve the competitiveness of an area's industries and provide American workers the skills and knowledge they need to obtain good-paying jobs (Duesterberg, 2016; Case Western Reserve University \& DOC, 2016). ${ }^{4}$ Spurred by growing federal investments in apprenticeships, an increasing number of states have expanded their own programs (White House, 2017). ${ }^{5}$ For example, in 2016, Pennsylvania established a new Office of Apprenticeship and Training, and increased apprentices statewide by nearly 10 percent (Pennsylvania's Governor's Office, 2017). European-style apprenticeship programs, closely involving manufacturers, unions and trade associations, are thriving in the Carolinas, Wisconsin, Georgia, Florida, Tennessee, and Michigan (Duesterberg, 2016). The Wisconsin-based Industrial Manufacturing Technician registered apprenticeship program fulfills the increased need of multiple employers for skilled manufacturing technicians (Berth, et.al., 2017). ${ }^{6}$ States should act to continue the momentum on apprenticeships by providing small grants and tax-credits to companies hosting apprenticeships, combined with aggressive marketing. They also should increase the involvement of community and technical colleges and establish pre-apprenticeship and pipeline programs with community-based organizations to ensure diverse access to apprenticeships.

- States and localities should work with industry and educational institutions to strengthen career and technical education (CTE) systems. For many years, students have been taught that a four-year college degree is the best pathway to career success. As a result, vocational high schools have all but died out in the United States, fueling the skills shortage that manufacturers complain about today (Wyman, 2015). High school vocational education, however, has been making a comeback. Federal and state policies have promoted increased 
investment in vocational high school programs - also known as Career and Technical Education (CTE) - to train students in occupational-specific technical skills needed to fill jobs in manufacturing, and other sectors. State and local agencies should promote industrylabor-academic partnerships with schools and community colleges to establish and expand CTE programs in their communities, leveraging existing both public sector (for example, WIOA, or the U.S. Department of Education) and private sector funding. They also should fund youth apprenticeship programs, allowing students to complete pre-apprenticeship coursework in CTE programs and to work on-the-job as apprentices during the school year while completing required instruction for apprenticeship at their high schools. Other measures include CTE programs adopting regional and nationally recognized skills standards and certificates and supporting branding programs that promote a positive perception of manufacturing to the public.

- Require and strengthen incentives for training and education initiatives to target vulnerable, dislocated and transitioning workers, especially in economically distressed areas. CTE strategies can promote social equity and inclusion, if provided the necessary resources, equipment, and skilled instructors, and are not places where disadvantaged students are tracked to inferior quality education. Although these measures move in the right direction-trying to bring along the "left behind" workers, creating opportunities to qualify for and obtain family-supporting jobs-federal and state programs must take stronger steps when providing grants or resources to promote economic inclusion. First, they should require businesses to diversify the pipeline of skilled, well-paid workers in work-based learning and other workforce initiatives and target public resources to businesses that want to provide family-supporting jobs. They also should provide lower-skilled or inexperienced hires preemployment training and other services to reach proficiency before starting at a worksite and promote supports during the first few months of employment while they learn new skills (NSC, 2017). They also should establish work-based learning funds to support out-of-school youth (and adults with limited work experience), as they transition to employer-sponsored apprenticeships or other work-based learning; provide pre-employment training grants for pre-apprenticeship services to community-based organizations, labor-management partnerships or industry-based intermediaries to support (NSC, 2017); and provide subsidies to employers for training disadvantaged workers facing barriers to employment.

- Strengthen and improve state (and federal) measures to support a comprehensive, wellresourced safety-net and system of social protections for dislocated workers. Safety net and social protections include income maintenance, retirement security, health care security, and other forms of support for workers who have experienced economic dislocation. State and federal workforce assistance programs must expand their investments to improve, expand, and make more whole social protections for workers in transition-displaced workers, longterm unemployed, individuals unable to work (due to disability, children) and retirees - and reduce the barriers to obtaining needed benefits. There must be sufficient income and benefit replacement to allow workers to maintain their standard of living, covering their living expenses and programs fees over a designated transition period, so they can complete their training program and move on to better opportunities. There also should be extended and improved Unemployment Insurance benefits to workers in training and improve approved training rules (Stettner, et.al., 2004), and older workers should be guaranteed an adequate bridge to retirement.

\section{Supportive Federal Policies}

States are particularly dependent on federal funds for workforce development initiatives, but federal programs have been too limited. A good example is Trade Adjustment Assistance (TAA) program which should be expanded by moving from the current standard of factory-by-factory certification to industryand occupation-wide certification and expanded to cover involuntary job losses to automation and climate 
policy. Moreover, to meet the priority of recruiting more diverse communities into manufacturing, key policy proposals like the Gateways to Careers Act and the Partners Act, that provide community organizations the resources to provide career counseling, case management, mentoring, and wraparound services like child care and transportation to workforce trainees should be enacted. And, with newfound attention to apprenticeship in Washington, resources should be dedicated to double manufacturing apprenticeships in five years (from 17,000 to 35,000 enrolled) and build the infrastructure for sectorbased education and training.

\section{Driver 4: Mobilize Responsible Capital for High Road Growth}

This driver would support the development and availability of well-resourced and accessible capital strategies and financing options to assist manufacturing revival and high-road recoveries in struggling industries and communities. Achieving the goals of manufacturing revival and economic recovery associated with the other regional drivers requires ready access to financial resources.

The lack of capital dedicated to manufacturing was of particular concern to Heartland stakeholders interviewed during this project. Most of U.S. venture capital is invested in software companies (57.4\%)when it comes to hard technologies that require manufacturing, the pattern is now "invent here and manufacture there." This investment trend has a major geographic impact: industrial states represent 32 percent of all U.S. employment but only 9.3 percent of all venture capital investment (Stettner, 2018). The lack of investment capital is a real everyday problem for manufacturers like QuickLoadz, a Cleveland summit attendee from Ohio's section of Appalachia, who'd like to scale up their business manufacturing their patented winch-free container trailers in Ohio, but may have to sell their technology to a larger manufacturer elsewhere.

A number of federal programs are designed to encourage and incentivize private sector investments in innovation, business, and economic and community development, while addressing public goals. ${ }^{7}$ State and local governments also can do a great deal to mobilize public and private capital and leverage federal resources for economically, socially, and environmentally responsible investments to revitalize economic distressed manufacturing communities in the nation's industrial regions. Measures that states should pursue to mobilize and expand private and public sector-supported, economically targeted, responsible investments include the following:

- State governments should expand capital for startups and the working capital needs of firms that grow manufacturing, launch public banks and "Make It in (Your State)" bonds. After years of budget cuts, most states need more capital to take hardware startups from a concept to commercial production. Various options for states have been proposed, including making it easier for crowd-source funding. Additional priority and resources should be given to firms that are responsibly retaining or restoring jobs. There is already a movement to advance public banks, and progressive bond initiatives could include "green bonds" and minibonds (small enough so average citizens can participate) that allow civic-minded investors to simultaneously save and boost the state economy.

- State and city pension funds, and other institutions, should adopt the United Nations Principles of Responsible Investments (PRI) and enact investment policies measures to comply with DOL 2015-1 guidance on economically targeted investments. Economically targeted pensions funds should invest in promoting in-state manufacturing and community development and ensuring sustainable investment in cities and communities. The global momentum of environmental, social, and governance (ESG) investing is borne out by performance meta-studies, which show that investors that invest responsibly and practice good corporate governance tend to enjoy financial outperformance (Croft \& Malhotra, 2016). Other reports have amalgamated performance studies on firms with good human resource practices, and found similar results (Beeferman \& Bernstein, 2015). States or groups of states should explore financial incentives for residents to save, or pool venture funds. They should support investments for in-state manufacturing and community development and 
sustainability in cities and communities, and explore financial incentives for state residents to save, or pool venture funds.

- Provide financial incentives for participative, high-road businesses. States should support firms that pay living wages and benefits, employee-owned and profit-sharing firms, and minority-owned firms and firms that source local materials and products. On the other hand, they should withdraw support for freeloader firms that pay low, unlivable wages and no benefits, thus requiring workers to apply for welfare to supplement wage. States also should support business succession programs to successfully transition the ownership to retiring owners to stakeholders or minority entrepreneurs.

\section{Supportive Federal Policies}

The federal government does little to specifically target the capital needs of manufacturers. A bold idea would be for a federal industrial bank can provide low-cost loans and loan guarantees to manufacturers. Like proposals for an infrastructure bank and the recent successful experiment with Build America Bonds, industrial bank funds would require that private lenders provide part of the funding for any supported project. Congress could fund the bank with revenue from tariffs targeting dumping, threats to national security, and unfair competition. Perhaps more immediately, the federal government could promote action by the private sector (and supported by pension funds) to promote the responsible investment movement by establishing an investment clearinghouse for sustainable, responsible, impact investing to work with various stakeholders to encourage investment management firms to develop new, innovative investment products to fill capital gaps. Another targeted strategy would be for the U.S. Small Business Administration should create a revolving loan fund that particularly targets small manufacturers, enabling them to upgrade their production equipment, cybersecurity, and networks, and install smart manufacturing technologies.

\section{CONCLUSION}

The resurgence of interest in industrial policy has translated into concrete actions in Washington, including new legislation by Congressional leaders and actions by the Trump Administration, especially through the Department of Defense, to address the critical needs outlined in this report and other reviews. However, by no means have federal or state governments committed to the comprehensive approach to industrial policy and economic recovery outlined above, and most policies pay little attention to issues of job quality that could badly exacerbate efforts to replenish the industrial workforce. For its part, the High Wage America initiative is focusing on proposal like a broad Trade, Policy and Technology Adjustment Assistance program that would give manufacturing communities the kind of tools long needed to address the magnitude of economic transitions. Moreover, the advanced manufacturing agenda outlined above can be a critical partner to proposals like the Green New Deal seeking to provide fairness and equity to all workers in an economy that is reducing its dependence on fossil fuels. Interestingly, the 2020 election provides an opening for a progressive discussion of the issue of manufacturing with a vision strongly linked to the needs of communities and working families to develop good paying jobs in the face of continuing economic transition.

\section{ENDNOTES}

1. The institutes build around the competencies of major research universities, in partnership with industry and state and local government programs, in large and medium-sized industrial cities, such as Pittsburgh, Detroit, Chicago, Youngstown, Raleigh, Albany, and San Jose, among others.

2. For example, the Small Business Innovation Research (SBIR) and Small Business Technology Transfer Research Programs (STTR) provide grants to small-and-medium sized enterprises for early state innovation $\mathrm{R} \& \mathrm{D}$, the Small Business Administration (SBA) provides financing for small businesses, with some programs targeting SMMs. 
3. Industry and sector partnerships enable the sharing of information, ideas and best practices among multiple employers; Because they focus on the needs of industries rather than single employers, they realize economies of scale in providing effective training and certification for multiple employers in an area. They also foster greater coordination of education and training providers with industry needs, leading to industry recognized credentials and common career pathways.

4. For example, 91 percent of apprentices find employment after completing their programs, with an average starting wage above $\$ 60,000$.

5. Fourteen states increased the number of apprentices by over 20 percent in 2015 , including Iowa, which tripled its funds for apprenticeships across key industries, and Georgia, which brought together its workforce development and community college systems to partner with over thirty major employers on apprenticeship.

6. Developed originally in Wisconsin, the AFL-CIO Working for America Institute, the Wisconsin Regional Training Partnership/BIG STEP and Jobs for the Future have now received federal funding to expand to eight additional states with a goal of registering 1,450 new IMT registered apprenticeships.

7. For example, the Small Business Innovation Research (SBIR) program; EDA's Revolving Loan Fund: Small Business Administration, Community Development Financial Initiatives.

\section{REFERENCES}

American Alliance for Manufacturing (AAM). (2016, November). Post-election survey results. https://aamweb.s3.amazonaws.com/uploads/resources/2016-Post-Election-Bipartisan-SurveyMemo Mellman NorthStar.pdf.

Arcelor Mittal. (2019). Cleveland. Retrieved May 30, from https://usa.arcelormittal.com/ouroperations/steelmaking/cleveland

Atkinson, R. D., \& Ezell, S. (2017, January 31). Ten Principles to Guide the Trump Administration's Manufacturing Strategy. Washington, DC: Information Technology \& Innovation Foundation. Retrieved from https://itif.org/publications/2017/01/31/ten-principles-guide-trumpadministrations-manufacturing-strategy.

Autor, D. H., Dorn, D., \& Hanson, G.H. (2013). The China Syndrome: Local Labor Market Effects of Import Competition in the United States. The American Economic Review, 103(6), 2121-2168. Retrieved from http://www.jstor.org/stable/42920646.

Beeferman, L., \& Bernstein, A. (2015, April). The Materiality of Human Capital to Corporate Financial Performance. Boston: Investor Responsibility Research Center Institute (IRRCI).

Berth, R., Dresser, L., \& Ubert, E. (2017, February). Moving Apprenticeship into Manufacturing's Future: Industrial Manufacturing Technician. Center for Wisconsin Strategy. Retrieved from http://www.cows.org/moving-apprenticeship-into-manufacturings-future-industrialmanufacturing-technician.

Block, F. (2017, September 20). A Strategy for Rebuilding the Manufacturing Sector in the United States. The Century Foundation. Retrieved from https://tcf.org/content/report/strategy-rebuildingmanufacturing-sector-united-states/.

Brown, S. (2018, March 12). Speech at Manufacturing a Better Paying Ohio Summit. Cleveland, Ohio. Retrieved from https://tcf.org/content/event/manufacturing-better-paying-ohio/?session=1.

Carter, J. (2012, February). Skilled Factory Workers or Cheap Skilled Factory Workers? Literacy and Policy. Retrieved from https://literacypolicy.org/2012/02/20/skilled-factory-workers-or-cheapskilled-factory-workers/.

Case Western Reserve University \& U.S. Department of Commerce (DOC). (2016, November). The Benefits and Costs of Apprenticeships: A Business Perspective. Retrieved from https://www.esa.gov/sites/default/files/the-benefits-and-costs-of-apprenticeships-a-businessperspective.pdf

Christopherson, S. (2009). Manufacturing: Up from the Ashes. Democracy Journal.Org, Fall, 25-30. Retrieved from https://democracyjournal.org/magazine/14/manufacturing-up-from-the-ashes/. 
Córdova, T., Wilson, M., \& A Stettner, A. (2018, June 6). Revitalizing Manufacturing and Expanding Opportunities for Chicago's Black and Latino Communities. The Century Foundation and the University of Illinois-Chicago, Great Cities Institute. Retrieved from https://tcf.org/content/report/revitalizing-manufacturing-expanding-opportunities-chicagos-blacklatino-communities/.

Council on Foreign Relations (CFR). (2016, January). No Helping Hand, Federal Worker-Retraining Policy. Renewing America Progress Report and Scorecard. Retrieved from https://www.cfr.org/report/no-helping-hand-federal-worker-retraining-policy.

Croft, T., \& Malhotra, A. (2016). The Responsible Investor Handbook. Leeds: Greenleaf Publishing.

Deloitte. (2017, January). Manufacturing USA, A Third-Party Evaluation of Program Design and

Progress. Deloitte Touche Tohmatsu Ltd. Retrieved from

https://www2.deloitte.com/content/dam/Deloitte/us/Documents/manufacturing/us-mfgmanufacturing-USA-program-and-process.pdf.

Delong. J. B. (2017). NAFTA and other trade deals have not gutted American manufacturing-period. Vox. Retrieved from https://www.vox.com/the-big-idea/2017/1/24/14363148/trade-deals-naftawto-china-job-loss-trump.

Duesterberg, T. (2016, September 14). How to Address the Skills Gap in the Manufacturing Economy. Paper prepared to U.S. Manufacturing and Public Policy Conference. National Press Club, Washington, DC.

Ezell, S., \& Atkinson, R. (2011, April). The Case for a National Manufacturing Strategy. Washington, DC: Information Technology and Innovation Foundation.

Fallows, J. (2016, June 5). Why the Maker Movement Matters: Part 1, The Tools Revolution? The Atlantic. Retrieved from https://www.theatlantic.com/business/archive/2016/06/why-the-makermovement-matters-part-1-the-tools-revolution/485720/.

Fallows, J. (2016, June 9). Why the Maker Movement Matters: Part 2, Agility. The Atlantic. Retrieved from https://www.theatlantic.com/business/archive/2016/06/why-the-maker-movement-mattersagility/486293/.

Fallow, J. (2016, June 18). More on the Public Role in Fostering Private Innovation. The Atlantic. Retrieved from https://www.theatlantic.com/notes/2016/06/more-on-the-public-role-in-fosteringprivate-innovation/487712/.

Fraunhoffer-Gesellschaft. (2015). Annual Report 2015. Focus on People. https://www.fraunhofer.de/en.html.

Gillespie, P. (2017, May 1). American manufacturing is having a moment. CNN. Retrieved from https://money.cnn.com/2017/05/01/news/economy/manufacturing-ism-2017/.

Goldin Peiser \& Peiser, LLP. (2015, December). How Manufacturing Incubators Are Moving Manufacturing Into the 21st Century. Retrieved from https://manufacturing.gppcpa.com/enewsletters/article/how-manufacturing-incubators-aremoving-manufacturing-into-the-21st-century/.

Harris, R. (2014). Ticket to a Job. Catalyst In Depth. Community Renewal Society, Winter. Retrieved from http://www.chicagoreporter.com/wp-content/uploads/assets/20140206/catalystindepthwinter2014f.pdf.

Helper, S., \& Tucker, T. (2016, September 15). We Need New Trade Policies, But Not Trump's. RealClearPolicy. Retrieved from http://www.realclearpolicy.com/blog/2016/09/15/how_to_make_american_manufacturing_great_ again.html.

Helper, S., Krueger, T., \& Wial, H. (2012, February). Why Does Manufacturing Matter? Which Manufacturing Matters? A Policy Framework. Washington, DC: Metropolitan Policy Program at Brookings Institution. Retrieved from https:/www.brookings.edu/wpcontent/uploads/2016/06/0222_manufacturing_helper_krueger_wial.pdf.

Hicks, M., \& Devaraj, S. (2015, June). The Myth and Reality of Manufacturing in America. Ball State University. Retrieved from http://projects.cberdata.org/reports/MfgReality.pdf. 
Houseman, S., Bartik, T., \& Sturgeon, T. (2014). Measuring Manufacturing: How the Computer and Semiconductor Industries Affect the Numbers and Perception. Upjohn Institute Working Paper 14-209. Kalamazoo, MI: W.E. Upjohn Institute for Employment Research. https://doi.org/10.17848/wp14-209.

Intrepid Advisors. (2016). State R\&D Tax Credit Eligibility Map. Retrieved from https://intrepidadvisors.com/state-rd-tax-credit-eligibility-map/.

Lake, R. W., Leichenko, R., \& Glasmeier, A.K. (2014, July). EDA and U.S. Economic Distress, 19652000. U.S. EDA. Retrieved from http:/www.ipsr.ku.edu/KUforKS/2004julyEDAandUSeconomicdistressreport.pdf.

Jacobs, K., Perla, Z., Perry, I.E., \& Graham-Squire, D. (2016, May 10). Producing Poverty: The Public Cost of Low-Wage Production Jobs in Manufacturing. UC Berkeley Center for Labor Research and Education, Institute for Research on Labor Employment. Retrieved from

http://laborcenter.berkeley.edu/producing-poverty-the-public-cost-of-low-wage-production-jobsin-manufacturing/

Jorgenson, D., \& Timmer, M. (2011). Structural Change in Advanced Nations: A New Set of Stylised Facts. Scandanavian Journal of Economics, 113, no. 1, 1-29.

https://scholar.harvard.edu/files/jorgenson/files/sje_jorgenson_timmer_publication.pdf.

Keystone Research Center (KRC). (2016). The Grow Good Manufacturing Jobs in Pennsylvania State Policy Agenda, January 17. In Alliance for American Manufacturing (AAM)-Economic Policy Institute (EPA)-Economic Analysis Research Network (EARN), Final Report to AAM from EARN-EPI Six-State Manufacturing Project 2016.

Made in NYC. (2019). Website. http://madeinnyc.org/about-us/.

Mahoney, T.C., \& Helper, S. (2017). Ensuring American Manufacturing Leadership Through NextGeneration Supply Chains. Mforesight, June. http://mforesight.org/projects-events/supplychains/.

Manufacturing Institute \& Deloitte. (2015). The Skills Gap in U.S. Manufacturing 2015 and Beyond. http://www.themanufacturinginstitute.org/ /media/827DBC76533942679A15EF7067A704CD.as $\mathrm{hx}$.

Manufacturing Institute \& Manufacturing Alliance for Productivity and Innovation (MAPI). (2012). Facts about Manufacturing. November.

http://www.themanufacturinginstitute.org/ /media/1242121E7A4F45D68C2A4586540703A5/20 12_Facts_About_Manufacturing__Full_Version__High_Res.pdf.

Mishel, L. (2018). Yes, manufacturing still provides a pay advantage, but staffing firm outsourcing is eroding it. Economic Policy Institute, March. https://www.epi.org/publication/manufacturingstill-provides-a-pay-advantage-but-outsourcing-is-eroding-it/

Moser, H. (2018). Reshoring Initiative 2018 Data Report: A Record 1,389 Companies Announce the Return of 145,000 Jobs. The Reshoring Initiative. http://reshorenow.org/content/pdf/Reshoring_Initiative_2018_Data_Report.pdf.

Moser, H. (2015). Reshoring Initiative Data Report: Reshoring and FDI Boost US Manufacturing in 2015. The Reshoring Initiative. http://reshorenow.org/blog/reshoring-initiative-data-reportreshoring-and-fdi-boost-us-manufacturing-in-2015/.

Muro, M. (2016). Adjusting to economic shocks tougher than thought. Brookings Institution. April 18. https://www.brookings.edu/blog/the-avenue/2016/04/18/adjusting-to-economic-shocks-tougherthan-thought/.

Muro, M., Rothwell, J., \& Saha, D. (2011). Sizing the Clean Economy, A National and Green Jobs Assessment. Washington, DC: Brookings Institution. https://www.brookings.edu/wpcontent/uploads/2016/07/0713_clean_economy.pdf.

NGA Center for Best Practices (NGA), National Network of Sector Partners (NNSP) \& Corporation for a Skilled Workforce (CSW). (2006). State Sector Strategies: Regional Solutions to Worker and Employer Needs. November 6. http://www.sectorstrategies.org/sites/all/files/State\%20Sector\%20Strategies\%20Brief.pdf. 
National Research Council (NRC). (2013). Best Practices in State and Regional Innovation Initiatives: Competing in the 21st Century. Charles W. Wessner (ed.). Washington, DC: The National Academies Press. https://doi.org/10.17226/18364.

National Science Board (NSB). (2016). Science and Engineering Indicators, 2016. https://www.nsf.gov/statistics/2016/nsb20161/\#/report/overview/science-and-technology-in-theworld-economy.

National Skills Coalition (NSC). (2017). Getting to Five Million Apprentices, Federal Options for Expanding Work-Based Learning," April. https://www.nationalskillscoalition.org/resources/publications/file/Getting-to-5-MillionApprentices-web.pdf.

Pennsylvania Department of Community and Economic Development (DCED). (2013). Make It in PA, A Statewide Plan for Reshoring Manufacturing and Optimizing Supply Chain Opportunities in Pennsylvania. Proposal.

Pennsylvania Governor's Office. (2017). Wolf Administration's Apprenticeship and Training Office Increasing Opportunities for Job Seekers and Employers in Pennsylvania. Newsroom, May 22. https:/www.governor.pa.gov/wolf-administrations-apprenticeship-and-training-office-increasingopportunities-for-job-seekers-and-employers-in-pennsylvania/.

Pisano, G.P., \& Shih, W.C. (2012). Producing Prosperity: Why America Needs a Manufacturing Renaissance, Cambridge: Harvard Business Press.

Pisano, G.P., \& Shih, W.C. (2009). Restoring American Competitiveness. Harvard Business Review, JulyAugust. https://hbr.org/2009/07/restoring-american-competitiveness.

Ramaswamy, S. (2017). Manufacturing trends in the United States, Extracts from McKinsey Global Institute research, January 2017. Presentation to forum "What Should the Trump Administration's Manufacturing Strategy Look Like.” Information Technology and Innovation Foundation, Washington, DC, January 31. http://www2.itif.org/2017-ramaswamy-manufacturingstrategy-presentation.pdf?_ga=2.38121184.2128588184.1506796920-1564628299.1506796920.

Russo, J. (2017). The Pittsburgh Conundrum. The American Prospect, Summer, 28-33. http://prospect.org/article/pittsburgh-conundrum.

Shropshire, C. (2017). First Step to New CTA Rail Cars: Build the Factory in Chicago. Chicago Tribune, March 16. https://www.chicagotribune.com/business/ct-cta-new-railcar-plant-0316-biz20170315-story.html.

Sirkin, H. L., Zinser, M., \& Rose, J. (2013). The U.S. Skills Gap: Could It Threaten a Manufacturing Renaissance? Boston Consulting Group, August. https://www.bcg.com/publications/2013/leanmanufacturing-us-skills-gap-could-threaten-manufacturing-renaissance.aspx.

Stettner, A. (2018). How Federal Government Can Foster Stateside Advanced Manufacturing. The Century Foundation, April 9, https://tcf.org/content/report/federal-government-can-fosterstateside-advanced-manufacturing/

Stettner, A., Croft, T., Shields, M., Yudken, J.S., Herzenberg, S., Mills, J., \& Veeder, C. (2019). 9 Steps to Revitalize America's Manufacturing Communities. The Century Foundation, May 8. https://tcf.org/content/report/9-steps-revitalize-americas-manufacturing-communities/.

Stettner, A.. \& Yudken, J.S. (2018). A Federal Agenda for Revitalizing America's Manufacturing Communities. The Century Foundation, September 13. https://tcf.org/content/report/federalagenda-revitalizing-americas-manufacturing-communities/.

Stettner, A., Yudken, J.S., \& McCormack, M. (2017). Why Manufacturing Jobs are Worth Saving. The Century Foundation, June 13. https://tcf.org/content/report/manufacturing-jobs-worth-saving/.

Stettner, A., Smith, S., \& McHugh, R. (2004). Changing Workforce, Changing Economy. National Employment Law Project, 55-65.

Thomas, K., \& Gillies, R. (2018). Trump: Trade deal returns US to manufacturing powerhouse. Associated Press, September 30. https://www.detroitnews.com/story/news/nation/2018/09/30/uscanada-trade-deal/38003623/. 
U.S. Bureau of Labor Statistics (BLS), (2018) Quarterly Census of Employment and Wages (QCEW), https://www.bls.gov/cew/

U.S. Bureau of the Census, Economic Indicators Division. (2019). Report FT900 (CB 19-112, BEA 1938). June. https://www.census.gov/foreign-trade/Press-Release/current_press_release/exh1.txt.

U.S. Department of Defense (DOD). (2018). Assessing and Strengthening the Manufacturing and Defense Industrial Base and Supply Chain resiliency of the United States. Report to President Donald J. Trump by the Interagency Task Force in Fulfillment of Executive Order 13806, September. https://media.defense.gov/2018/Oct/05/2002048904/-1/-1/1/ASSESSING-ANDSTRENGTHENING-THE-MANUFACTURING-AND\%20DEFENSE-INDUSTRIAL-BASEAND-SUPPLY-CHAIN-RESILIENCY.PDF.

U.S. Department of Labor (DOL). (2012). Layoff Aversion in Rapid Response Systems. Training and Employment Notice 9-12, August 31. https://wdr.doleta.gov/directives/attach/TEN/TEN_9_12_Acc.pdf.

U.S. Department of Labor (DOL), Bureau of Labor Statistics (BLS). (2017). Labor Force Statistics from the Current Population. https://www.bls.gov/cps/cpsaat18.htm.

U.S. Economic Development Administration (EDA). (2015). Comprehensive Development Strategy (CEDS) Content Guidelines, Recommendations for Creating an Impactful CEDS. https://www.eda.gov/ceds/.

van Agtmael, A., \& Bakker, F. (2016). The Smartest Places on Earth, Why Rustbelts are the Emerging Hotspots of Global Innovation. New York: Public Affairs.

Vijaya, R. M. (2010). Broken Buffer: How Trade Adjustment Assistance Fails American Workers. Dëmos. http://www.demos.org/.

Weaver, A., \& Osterman, P. (2017). Skill Demands and Mismatch in U.S. Manufacturing. ILR Review 70, no. 2 (March), 275-307. http://journals.sagepub.com/doi/abs/10.1177/0019793916660067.

White House. (2017). Presidential Executive Order Expanding Apprenticeships in America. June 15. https://www.whitehouse.gov/the-press-office/2017/06/15/presidential-executive-order-expandingapprenticeships-america.

Wyman, N. (2015). Why We Desperately Need To Bring Back Vocational Training In Schools. Forbes, September 2. https://www.forbes.com/sites/nicholaswyman/2015/09/01/why-we-desperatelyneed-to-bring-back-vocational-training-in-schools/2/\#7c1674f256f8.

Yudken, J. (2010). Manufacturing Insecurity: America's Manufacturing Crisis and the Erosion of the U.S. Defense Industrial Base. Washington, DC: AFL-CIO Industrial Union Council, September. https://digitalcommons.ilr.cornell.edu/laborunions/40/

Yudken, J. S., Croft, T., \& Stettner, A. (2017). Revitalizing America's Manufacturing Communities. The Century Foundation, October 16. https://tcf.org/content/report/revitalizing-americasmanufacturing-communities/. 


\section{APPENDIX \\ STATE MANUFACTURING EMPLOYMENT}

\begin{tabular}{|c|c|c|c|c|c|c|c|}
\hline \multirow[b]{2}{*}{ State } & \multicolumn{3}{|c|}{ Manufacturing Employment Level } & \multicolumn{3}{|c|}{ Change in Employment } & \multirow[b]{2}{*}{$\begin{array}{c}\text { Manufacturing } \\
\text { as a \% of } \\
\text { Private Sector } \\
\text { Jobs }\end{array}$} \\
\hline & $\begin{array}{c}\text { January } \\
2001\end{array}$ & $\begin{array}{c}\text { January } \\
2010\end{array}$ & $\begin{array}{c}\text { March } \\
2019\end{array}$ & $\begin{array}{c}\text { Jobs } \\
\text { Lost } \\
2001- \\
2010 \\
\end{array}$ & $\begin{array}{c}\text { Job } \\
\text { Gains } \\
2010- \\
2016 \\
\end{array}$ & $\begin{array}{c}\text { Job } \\
\text { Gains } \\
2017- \\
2019 \\
\end{array}$ & \\
\hline Indiana & 639 & 440 & 544 & -200 & 79 & 25 & $19.8 \%$ \\
\hline Wisconsin & 583 & 424 & 476 & -159 & 50 & 2 & $18.5 \%$ \\
\hline Iowa & 248 & 199 & 228 & -50 & 10 & 19 & $17.2 \%$ \\
\hline Michigan & 846 & 453 & 637 & -392 & 143 & 41 & $16.6 \%$ \\
\hline Alabama & 336 & 237 & 271 & -100 & 29 & 6 & $16.1 \%$ \\
\hline Mississippi & 212 & 137 & 146 & -75 & 4 & 5 & $15.9 \%$ \\
\hline Kentucky & 303 & 208 & 255 & -96 & 38 & 9 & $15.6 \%$ \\
\hline Arkansas & 236 & 158 & 165 & -78 & -6 & 13 & $15.6 \%$ \\
\hline Ohio & 998 & 612 & 702 & -386 & 77 & 12 & $14.6 \%$ \\
\hline Kansas & 198 & 158 & 167 & -40 & 3 & 7 & $14.4 \%$ \\
\hline South Carolina & 329 & 206 & 255 & -124 & 37 & 13 & $14.2 \%$ \\
\hline Tennessee & 476 & 298 & 356 & -179 & 46 & 13 & $13.4 \%$ \\
\hline Minnesota & 394 & 288 & 320 & -106 & 28 & 4 & $12.6 \%$ \\
\hline South Dakota & 43 & 36 & 46 & -7 & 5 & 5 & $12.6 \%$ \\
\hline North Carolina & 745 & 431 & 475 & -313 & 32 & 12 & $12.5 \%$ \\
\hline Oregon & 225 & 163 & 200 & -62 & 24 & 14 & $12.2 \%$ \\
\hline Vermont & 47 & 30 & 31 & -17 & 0 & 1 & $11.8 \%$ \\
\hline New Hampshire & 104 & 65 & 70 & -39 & 2 & 3 & $11.7 \%$ \\
\hline Nebraska & 114 & 91 & 99 & -23 & 5 & 2 & $11.6 \%$ \\
\hline Missouri & 359 & 244 & 278 & -115 & 15 & 18 & $11.3 \%$ \\
\hline Idaho & 71 & 53 & 70 & -18 & 12 & 5 & $11.2 \%$ \\
\hline Illinois & 851 & 554 & 594 & -297 & 12 & 28 & $11.1 \%$ \\
\hline Connecticut & 234 & 165 & 161 & -70 & -5 & 2 & $11.1 \%$ \\
\hline Pennsylvania & 856 & 557 & 566 & -299 & 10 & -1 & $10.6 \%$ \\
\hline Utah & 126 & 111 & 137 & -15 & 18 & 8 & $10.6 \%$ \\
\hline Georgia & 531 & 343 & 410 & -187 & 44 & 23 & $10.5 \%$ \\
\hline Washington & 327 & 258 & 296 & -69 & 26 & 12 & $10.2 \%$ \\
\hline Oklahoma & 176 & 121 & 137 & -54 & 5 & 11 & $10.2 \%$ \\
\hline Maine & 78 & 51 & 53 & -27 & -1 & 3 & $10.0 \%$ \\
\hline Rhode Island & 72 & 41 & 40 & -31 & 0 & -1 & $9.2 \%$ \\
\hline California & 1868 & 1244 & 1336 & -624 & 39 & 53 & $9.1 \%$ \\
\hline Texas & 1067 & 814 & 904 & -252 & 30 & 60 & $8.4 \%$ \\
\hline Louisiana & 177 & 137 & 138 & -41 & -4 & 5 & $8.3 \%$ \\
\hline
\end{tabular}




\begin{tabular}{|c|c|c|c|c|c|c|c|}
\hline \multirow[b]{2}{*}{ State } & \multicolumn{3}{|c|}{ Manufacturing Employment Level } & \multicolumn{3}{|c|}{ Change in Employment } & \multirow[b]{2}{*}{$\begin{array}{c}\text { Manufacturing } \\
\text { as a } \% \text { of } \\
\text { Private Sector } \\
\text { Jobs }\end{array}$} \\
\hline & $\begin{array}{c}\text { January } \\
2001\end{array}$ & $\begin{array}{c}\text { January } \\
2010\end{array}$ & $\begin{array}{c}\text { March } \\
2019\end{array}$ & $\begin{array}{c}\text { Jobs } \\
\text { Lost } \\
2001- \\
2010 \\
\end{array}$ & $\begin{array}{c}\text { Job } \\
\text { Gains } \\
2010- \\
2016 \\
\end{array}$ & $\begin{array}{c}\text { Job } \\
\text { Gains } \\
2017- \\
2019 \\
\end{array}$ & \\
\hline West Virginia & 75 & 49 & 48 & -26 & -2 & 2 & $8.2 \%$ \\
\hline Massachusetts & 410 & 253 & 244 & -156 & -2 & -8 & $7.6 \%$ \\
\hline North Dakota & 24 & 22 & 26 & -2 & 2 & 2 & $7.5 \%$ \\
\hline Virginia & 356 & 233 & 246 & -123 & -3 & 17 & $7.4 \%$ \\
\hline Arizona & 210 & 148 & 175 & -62 & 12 & 15 & $7.0 \%$ \\
\hline New Jersey & 415 & 253 & 250 & -162 & -12 & 9 & $7.0 \%$ \\
\hline Delaware & 39 & 27 & 28 & -12 & 0 & 1 & $6.9 \%$ \\
\hline Colorado & 186 & 123 & 149 & -63 & 17 & 8 & $6.4 \%$ \\
\hline Alaska & 10 & 13 & 14 & 3 & 3 & -2 & $5.4 \%$ \\
\hline New York & 739 & 458 & 444 & -281 & -15 & 1 & $5.4 \%$ \\
\hline Montana & 22 & 17 & 20 & -5 & 3 & 0 & $5.2 \%$ \\
\hline Florida & 470 & 309 & 380 & -161 & 47 & 25 & $4.9 \%$ \\
\hline Maryland & 170 & 116 & 108 & -54 & -8 & 0 & $4.8 \%$ \\
\hline Wyoming & 11 & 9 & 10 & -2 & 1 & 1 & $4.7 \%$ \\
\hline Nevada & 44 & 38 & 59 & -6 & 4 & 16 & $4.7 \%$ \\
\hline New Mexico & 42 & 29 & 27 & -13 & -3 & 1 & $4.1 \%$ \\
\hline Hawaii & 17 & 13 & 14 & -4 & 0 & 0 & $2.6 \%$ \\
\hline
\end{tabular}

Source: BLS's CES State and Metro Area Employment, Hours, \& Earnings 